Od narodzin przez stulecia trwał niezmienny krąg istnienia. Wytyczony przez teren. Tych, którzy go przekraczali, pochłaniał ogień. Powiększyliśmy granice istnienia. Poszerzyliśmy krąg. Śmierć oddaliliśmy o dziesięciolecia. Czas życia wydłużył się w ostatnim stuleciu o dwadzieścia pięć lat. Każdemu z nas przydano ćwierć wieku życia. I ten naddatek, wbrew wstępnym prognozom demografów rośnie. Życia wciąż przybywa. W ciągu ostatnich dziesięciu lat średni czas życia $w$ krajach rozwiniętych przyrasta $\mathrm{z}$ szybkością około pięciu godzin dziennie. Pomyślmy o tym następująco: każdy $z$ nas budzi się rano do dwudziestodziewięciogodzinnego dnia. $Z$ tego dwadzieścia cztery godziny zużyjemy teraz, pięć godzin odłożymy na później. Tak wydłuża się - w nas - nasze życie. A jeśli śmierć przyjdzie wcześniej, nie zawahamy się wyrwać jej ofiary, przywrócić istnienie.

A. Szczeklik, Nieśmiertelność, s. 141. 


\section{O DOŚWIADCZENIU ŚMIERCI*}

\section{1.}

Czy można mówić o doświadczeniu śmierci? Jeśli wierzyć Epikurowi, nie jest to możliwe:

Śmierć, najstraszniejsze z nieszczęść wcale nas nie dotyczy, skoro bowiem my istniejemy, śmierć jest nieobecna, a skoro tylko śmierć się pojawi, nas wtedy już nie ma ${ }^{1}$.

Epikur mówi o naszej, czyli naszej własnej śmierci. Wypada się z nim zgodzić: mowa jest wszak o śmierci, a więc szczególnym, momentalnym zdarzeniu kończącym nasze życie, nie o umieraniu. To bowiem, jako proces, może być doświadczane, i wiemy, że bywa doświadczane w sposób dramatyczny.

W rozważaniach, którym pragnę poświęcić niniejszy rozdział, chodzi o jeszcze inne doświadczenie śmierci: nie mojej własnej, lecz śmierci drugiego. Na ten temat napisano wiele. Szczególnie wiele opisów i refleksji znajdujemy w literaturze: w dramacie, beletrystyce, w poezji. I właśnie na tej ostatniej, na doświadczeniu poetyckim, sięgającym przecież często o wiele głębiej, niż filozofia, chciałbym oprzeć te rozważania² ${ }^{2}$ Zamysł podstawowy jest jednak natury filozoficznej: chodzi o wydobycie tych momentów, które zdają się istotne dla doświadczenia śmierci innego, przybliżając możliwie pełną charakterystykę konstytuujących je przeżyć.

* Tekst publikowany wcześniej w: W. Stróżewski, O wielkości. Szkice z filozofii człowieka, Znak, Kraków 2002, s. 133-157 (przedruk za zgodą Autora).

${ }^{1}$ Epikur z Samos, List do Menojkeusa, [w:] J. Legowicz, Filozofia starożytna Grecji i Rzymu, Państwowe Wydawnictwo Naukowe, Warszawa 1968, s. 246.

2 Filozofia śmierci, obecna $\mathrm{w}$ dziełach największych myślicieli, od Platona po Heideggera i Jaspersa, wymagałby zupełnie innego opracowania, którego nie jesteśmy tu w stanie przeprowadzić. 
Wróćmy jednak na chwilę do zdania Epikura. Wynika z niego, że śmierć radykalnie wyklucza się z życiem. Ściślej powiedziawszy: śmierć wykluczona jest przez ideę życia. Nie jest jednak wykluczona przez ideę żyjącego (tego, co żyje).

Dlaczego tak się dzieje? Wydaje się, że pojęcie życia wiąże się ściśle z pojęciami trwania i samoaktywności ${ }^{3}$. „Trwanie” ma sens o tyle, o ile wyklucza możliwość swego kresu. W tym sensie "życie” staje się znaczeniowo bliskie „istnieniu”. Moment samoaktywności zdaje się odsyłać do immanentnej siły, która zapewnia procesowi życia nieustanny „napęd”. „Czyste" istnienie nie zawiera $\mathrm{w}$ sobie momentu nieistnienia, który odkrywamy $\mathrm{w}$ tym, co istnieje (bycie, istniejącym). Tę analogię zdajemy się przenosić na "czyste" życie, w którym - w przeciwieństwie do żyjącego (istoty żyjącej), nie znajdujemy momentu śmierci.

Przeciwieństwo: życie - śmierć wykorzystał Platon w jednym $\mathrm{z}$ argumentów na rzecz nieśmiertelności duszy, jakie przedstawił w Fedonie. Skoro dusza „...opanowując jakąś rzecz, zawsze wnosi do niej życie”, tym samym nie może przyjąć przeciwieństwa tego, co z sobą wprowadza, pozostaje więc nieśmiertelna i niezniszczalna. „Gdy więc Śmierć zaatakuje człowieka, to jego część śmiertelna, jak się wydaje, umiera, jego zaś część nieśmiertelna, cała i nietknięta, odchodzi i wycofuje się, ustępując miejsca śmierci" ${ }^{\prime}$.

Ale nawet w istocie żyjącej dokonuje się swoiste "zwycięstwo" życia nad śmiercią: $w$ każdym momencie życia tej istoty przezwyciężana jest przecież grożąca jej śmierć.

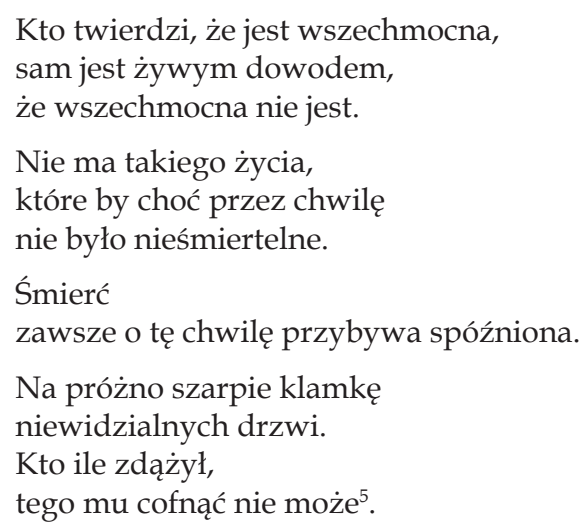

Czy na co dzień żyjemy ideą życia raczej niż ideą żyjącego? I czy dlatego tak mało myślimy o śmierci?

\footnotetext{
${ }^{3}$ Zob. H. Promieńska, Trwanie i zmiana wartości moralnych, Wydawnictwo Uniwersytetu Śląskiego, Katowice 1991, s. 43 i n.

${ }^{4}$ Platon, Fedon, 105d-106e, przeł. R. Legutko, Znak, Kraków 1995, s. 258-260.

${ }^{5}$ W. Szymborska, O śmierci bez przesady, [w:] taż, Widok z ziarnkiem piasku. 102 wiersze, Wydawnictwo a5, Poznań 1996, s. 111.
} 


\section{2.}

Pozostaje faktem, że o śmierci myślimy „na co dzieńn” rzadko, że raczej odsuwamy od siebie myśl i o niej samej, i o jej nieuchronnoścíi Bywa jednak, że coś nieprzewidywalnego i nieokreślonego zmusza nas nagle do refleksji nad naszą skończonością i każe myśleć o śmierci. Śmierć jawi się jednak nie tylko w naszych myślach; zdajemy się odczuwać jej obecność, paradoksalną obecność nieobecności, którą prędzej czy później śmierć spowoduje. Doświadczamy kruchości istnienia, możliwości zniweczenia tego, co jest wokół nas, i czym jesteśmy my sami, a odnosząc to doświadczenie do tego, co żyje, dostrzegamy z przerażającą jasnością, że każde żyjące nosi w sobie śmierć.

Kiedy myślę o naszym domu, gdzie teraz nie ma już nikogo, wtedy sądzę, że wówczas musiało być inaczej. Dawniej wiedziano (albo może domyślano się), że śmierć człowiek nosi w sobie jak owoc pestkę. Dzieci miały w sobie małą, a dorośli dużą. Kobiety miały ją w łonie, a mężczyźni w piersi. Dość, że się ją miało - a to dawało człowiekowi osobliwą, dostojną i cichą jakąś dumę

Przejmujący jest opis śmierci, jaki Rilke roztacza dalej, śmierci starego szambelana Krzysztofa Detlefa Brigge na Ulsgaardzie. Śmierć przepełniała komnaty dworu, płoszyła zwierzęta, wyła, krzyczała, żądała... „Przyszła na dziesięć tygodni i tak też długo pozostała. A w tym czasie więcej była panem, niż panem był kiedykolwiek Krzysztof Detlef Brigge, była jak król, którego nazywają Groźnym później i zawsze"8.

Doświadczenie obecności może mieć i inny wymiar, bodaj jeszcze bardziej egzystencjalny i bardziej uniwersalny niż w przytoczonym opisie Rilkego.

Błogosławiona niech będzie ta chwila,

kiedy się rodzi wieczorny hymn duszy!...

(...)

Z zapadłych wiosek płyną rozhowory,

w bagniskach dzikie obzywa się ptactwo,

a gdzieś w pustkowiu, a gdzieś na rozstaju

w samotnej chacie połyskuje światło,

a tam! z daleka cicha idzie Śmierć.

$(\ldots)$

${ }^{6}$ Nie będziemy teraz dociekali, dlaczego tak się dzieje. Na ogół zwraca się uwagę na to, że myśl o śmierci każe nam odsuwać szczególny życiowy pragmatyzm, konieczność „wychylania się" w przód, co byłoby niemożliwe, gdybyśmy nieustannie oczekiwali, że lada chwila nasze działanie ulegnie przerwaniu. Ale z pewnością zachodzą i inne przyczyny; wśród nich nie można nie zauważyć i zwykłego lęku przed śmiercią, o którym wolimy nie myśleć „na co dzień”.

${ }^{7}$ R.M. Rilke, Malte. Pamiętniki Malte-Lauridsa Brigge, przeł. W. Hulewicz, słowo wstępne M. Jastrun, Czytelnik, Warszawa 1958, s. 19-20.

${ }^{8}$ Tamże, s. 25. 


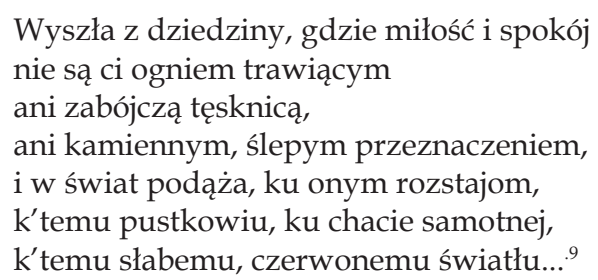

Doświadczenie obecności śmierci obejmuje nie tylko świat człowieka: rozciąga się na całość dostępnego nam świata. Jej najbardziej widocznym symptomem jest powolne zanikanie funkcji życiowych, zastępowanie wzrostu procesami zepsucia. Nie ma istoty żywej, która nie podlegałaby temu prawu.

Ah! na tym świecie Śmierć wszystko zmiecie, robak się lęgnie i w bujnym kwiecie ${ }^{10}$.

Romantycznemu poecie wtórował Jan Kasprowicz, z jednakową ostrością widzący symbol nieuniknioności śmierci w próchniejącej limbie:

W Ciemnosmreczyłskich skał zwaliska,

Gdzie pawiookie drzemią stawy,

Krzak dzikiej róży pąs swój krwawy

Na plamy szarych złomów ciska.

U stóp mu bujne rosną trawy,

Bokiem się piętrzy turnia śliska,

Kosodrzewiny wężowiska

Poobszywały głaźne ławy...

Samotny, senny, zadumany,

Skromnie do ziemi tuli ściany,

Jakby się lękał tchnienia burzy.

Cisza... O liście wiatr nie trąca,

A tylko limba próchniejąca

Spoczywa obok krzaku róży ${ }^{11}$.

I jeszcze raz Rilke. W słynnym, krótkim wierszu zamknął prawdę o ostatecznym zwycięstwie śmierci. Niech ten wiersz stanowi kontrapunkt do przytoczonego wcześniej fragmentu wiersza Szymborskiej:

Wielka jest śmierć.

Myśmy w jej mocy,

czy w smutku chwili,

\footnotetext{
${ }^{9}$ J. Kasprowicz, Moja pieśń wieczorna, [w:] tenże, Wybór poezji, oprac. J.J. Lipski, Ossolineum, Wrocław 1973, s. 202-203.

${ }^{10}$ A. Malczewski, Maria, oprac. R. Przybylski, wyd. 3, Zakłady Narodowe im. Ossolińskich, Wrocław-Kraków 1958, pieśń II, w. 733-734.

${ }^{11}$ J. Kasprowicz, Wybór poezji, dz. cyt., s. 130.
} 
czy w śmiechu czas.

Choćbyśmy w środku życia być sądzili, waży się kwilić

pośrodku nas ${ }^{12}$.

\section{3.}

To szczególne doświadczenie obecności nieobecności, przechodzące ze stanu przeczucia w refleksją , ,jeszcze nie", gdy przez moment o owej nieobecności pomyślimy, nieuchronnie sygnalizuje chwilę, w której śmierć przetnie nić czyjegoś życia.

„Jeszcze nie" wyparte zostaje przez "stało się", zawsze nieodwołalne i zawsze wyrażone $\mathrm{w}$ czasie przeszłym... W tym samym momencie ujawnia się z całą ostrością szczególny negatywny stan rzeczy, którego nie da się zastąpić niczym pozytywnym: pustka, brak, nicość ${ }^{13}$. Jeśli istnieje doświadczenie nicości (w co, jak wiadomo, wątpią niektórzy myśliciele ${ }^{14}$ ), to nigdzie nie dochodzi ono do głosu pełniej i wyraziściej niż w obliczu śmierci.

Wielkieś mi uczyniła pustki w domu moim,

Moja droga Orszulo, tym zniknieniem swoim! ${ }^{15}$

- słowa wielkiego poety przejmują po dziś swą tragiczną prawdą. Oto pustka, której nic i nikt nie zapełni, brak, którego nikt i nic nie zastąpi. Tę pustkę przeżywają nie tylko ludzie: zdaje się, że odczuwają ją także zwierzęta:
Umrzeć - tego nie robi się kotu.
Bo co ma począć kot
W pustym mieszkaniu.
Wdrapywać się na ściany.
Ocierać między meblami.
Nic niby tu nie zmienione,
a jednak pozamieniane.
Niby nie przesunięte,
a jednak porozsuwane.
I wieczorami lampa już nie świeci.

\footnotetext{
${ }^{12}$ R.M. Rilke, Poezje w przekładach Artura Sandauera, wyd. 2, PIW, Warszawa 1987, s. 59.

${ }^{13}$ Znakomicie opisuje to doświadczenie ks. J. Tischner: „Między pełną obecnością człowieka obok nas a pełną obecnością ścian, powietrza, jego mebli, bez człowieka, zjawia się bolesna sprzeczność. Bodaj najtrafniej wyrażają ten stan słowa »jego nie ma«. Słówko »nie ma« ma tutaj nieco inne znaczenie, niż mogłoby mieć słówko »nie istnieje«. Jest w nim ukryty jakiś subtelny ładunek emocjonalny, ono jest pełne tragedii, którą wszystkie inne słowa raczej fałszują, niż odsłaniają. (...) Słowa "nie istnieje oznaczają nicość - nieobecność obecności, natomiast słowa »nie ma go« oznaczają próżnię - żywą obecność nieobecności" (Świat ludzkiej nadziei, Wydawnictwo Znak, Kraków 1975, s. 274).

${ }^{14}$ Należą do nich tak wielcy, jak H. Bergson i B. Russell.

15 J. Kochanowski, Dzieła polskie, t. 2, oprac. J. Krzyżanowski, PIW, Warszawa 1952, s. 66.
} 


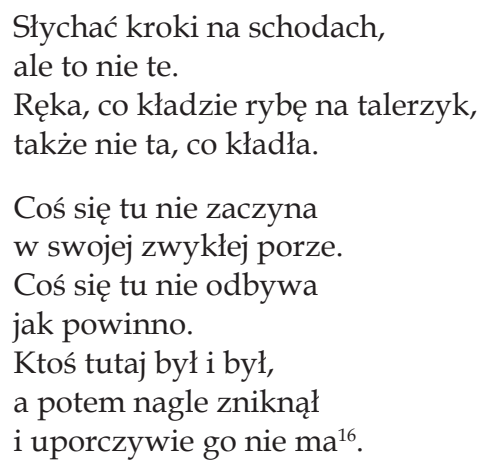

Doświadczenie niebytu dotyczy w pierwszym rzędzie tego, kogo właśnie zabrakło, ale piętnuje także rzeczywistość, która go otaczała, bliższą i dalszą, a która teraz pozostaje nadal przedmiotem naszego doświadczania. Ale doświadczenie to jest dla nas inne, niż było wcześniej: świat stał się podmiotem braku, stał się mniejszy o to, co w nim było integralnie wtopione w jego całość, a co teraz zniknęło na zawsze. Śmierć drugiego umniejsza także w jakiś sposób nas samych. Realna relacja, w jakiej pozostawaliśmy wobec drugiego, traci sens, znika. To, co bogaciło nas, gdy staliśmy twarzą w twarz wobec niego, co bogaciło nas na co dzień dzięki obcowaniu z nim, należy już do przeszłości. Może dopiero wtedy widzimy, jak wiele zawdzięczamy innym, jak bardzo współkonstytuuje nas stosunek ja - ty.

Nikt nie jest wyspą, wypełniającą samą siebie; każdy człowiek jest fragmentem kontynentu, częścią lądu. Jeśli morze zmyje choćby grudkę ziemi, Europa będzie umniejszona tak samo, jak gdyby pochłonęło przylądek, włość twoich przyjaciół czy twoją własną. Śmierć każdego człowieka umniejsza mnie, albowiem jestem zespolony z ludzkością. Przeto nigdy nie pytaj, komu bije dzwon: bije on tobie ${ }^{17}$.

Związane ze śmiercią metafizyczne doświadczenie braku dochodzi do przejmującej skargi także w wierszu Leśmiana Do siostry:

I sam nagle $\mathrm{w}$ tym słońcu musiałem pozostać.

Patrzyłem szynom w ślad...

Świat się zmniejszył na zawsze o twą drobną postać,

I zmalał cały świat!

$(\ldots)$

${ }^{16}$ W. Szymborska, Kot w pustym mieszkaniu, [w:] taż, Widok z ziarnkiem piasku..., dz. cyt., s. 155.

17 J. Donne, Poems and Devotions, R. van de Weyer (ed.), London 1995, s. 162 (No man is an island, entire of itself; every man is a piece of the continent, a part of the main. If a clod be washed away by the sea, Europe is the less, as well as if a promontory were, as well as if a manor of thy friend's or of thine own were: any man's death diminishes me, because I am involved in mankind, and therefore never send to know for whom the bell tolls; it tolls for thee). 
Noc, przy zmarłym spędzona, nazywa się - pusta!

Brak tego, o kim łkasz...

Zgniją oczy - i wyraz tych oczu - i usta.

śmierć patrzy w kość, nie w twarz!... ${ }^{18}$

Podobny motyw, ale jakby mniej dramatyczny, chciałoby się rzec: bardziej intymny, bo skierowany, w przedziwnym zamyśleniu, na własny los podmiotu lirycznego, znajdujemy w krótkim, przejmującym wierszu Haliny Poświatowskiej:

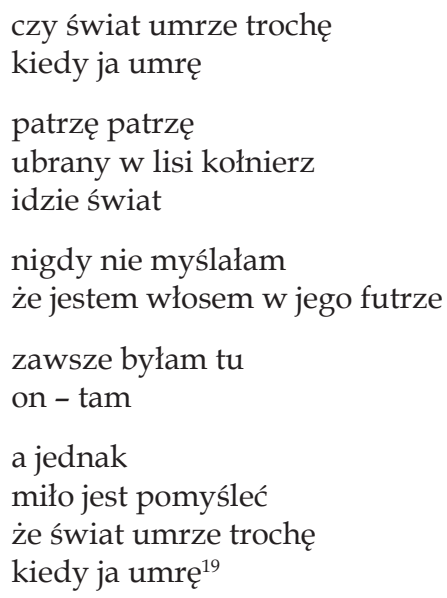

Na jeszcze jeden wymiar śmierci - braku wskazuje R.M. Rilke. Jest to wymiar z istoty swej metafizyczny, ale sięgający tajemnicy, do której śmiertelnikowi nie godzi się zbliżać. Czy wolno to uczynić poecie? Czy wolno mu spojrzeć na śmierć od strony Boga? Ten wiersz przejmuje trwogą. A zarazem jest świadectwem odwagi, jeśli nie wręcz zuchwałości - ostatecznej wobec ostateczności:
Co zrobisz, gdy ja umrę, Panie?
Jam dzban twój (kiedy zbiją się w kawały?)
Jam napój twój (kiedy się kwaśny stanie?)
Jam twe rzemiosło, twe ubranie,
beze mnie stracisz sens twój cały.
Beze mnie, po mnie, dom postradasz,
w którym cię bliskie słowa grzały.
Spadnę z twych ciężkich stóp jak spada
ten, którym jest twój aksamitny sandał.

${ }^{18}$ B. Leśmian, Poezje, wstęp i oprac. J. Trznadel, Agencja Wydawnicza Morex, Warszawa 1994, s. 320 .

${ }^{19}$ H. Poświatowska, Wiersze wybrane, wstęp i wybór J. Zycha, Wydawnictwo Literackie, Kraków 1989, s. 324. 
Twój płaszcz nie będzie ci osłoną.

Twój wzrok, który jak ciepłym łożem

wdycham policzkiem moim, Boże,

szukać mnie będzie w każdej porze,

aż go utuli o wieczorze

obcych kamieni zimne łono.

Co będzie z Tobą? Ja się trwożę $e^{20}$.

O jakiej śmierci myśli tu poeta? Jakaż śmierć umniejszyć może nawet Boga? Czy aż tak związał się On ze swym stworzeniem, że jego znicestwienie sięga samego Stwórcy? Czy miłość człowieka potrzebna jest Bogu tak, jak miłość Boga - człowiekowi? Buberowska relacja Ja-Ty została tu odwrócona. Byt Boga zostaje uzależniony od bytu człowieka. Tego nie da się pojąć, i jeśli poezja sięga rzeczy, „o których nie śniło się filozofom”, musimy w milczeniu oddać to pole poecie...

\section{4.}

Reperkusje każdej śmierci umniejszają całość bytu, ona sama pozostaje jednak zdarzeniem radykalnie indywidualnym. Raz jeszcze odwołajmy się do Rilkego:

A gdy myślę o tych innych, których widziałem lub o których słyszałem: zawsze to samo. Wszyscy oni mieli własną śmierć. Ci mężowie, którzy ją nosili w zbroi, wewnątrz, jak więźnia, te kobiety, co stawały się stare i małe i potem na olbrzymim łożu, niby na otwartej scenie, wobec całej familii, służby i psów, dyskretnie i po magnacku

20

Was wirst du tun, Gott, wenn ich sterbe?

Ich bin dein Krug (wenn ich zerscherbe?)

Ich bin dein Trank (wenn ich verderbe?)

Bin dein Gewand und dein Gewerbe,

mit mir verlies du deinen Sinn.

Nach mir hast du kein Haus, darin

dich Worte, nah und warm, begrussen.

Es fallt von deinen muden Fussen

die Samtsandale, die ich bin.

Dein grosser Mantel lasst dich los.

Dein Blick, den ich mit meiner Wange

warm, wie mit einem Pfuhl, empfange,

wird kommen, wird mich suchen, lange-

und legt beim Sonnenuntergange

sich fremden Steinen in den Schooss.

Was wirst du tun, Gott? Ich bin bange.

R.M. Rilke, Poezje, przeł. M. Jastrun, Wydawnictwo Literackie, Kraków 1974, s. 10-11. 
oddawały ducha. I dzieci, nawet najmniejsze, miały nie jakąkolwiek dziecięcą śmierć - lecz skupiały się w sobie i umierały tym, czym już były, i tym, co byłoby z nich wyrosło ${ }^{21}$.

Tak jest - i tak być powinno. Bo człowiekowi grozi, że odejdzie nie tak, jak odejść powinien, nie śmiercią własną, a to znaczy: dojrzałą, do której dorasta przez życie, niezależnie od życia tego długości, lecz jakąś przypadkową, przecinającą jego dni, gdy nie jest jeszcze do śmierci gotowy. Czy tak nie zdarza się zresztą najczęściej? Dlatego głęboki sens ma modlitwa o śmierć własną i dojrzałą zarazem. Zwróćmy uwagę na początek jeszcze jednego wiersza Rilkego; wrócimy do niego, w całości, pod koniec naszych rozważań:

Każdemu daj śmierć jego własną, Panie.

Daj umieranie, co wynika z życia,

gdzie miał swą miłość, cel i biedowanie.

Myśmy łupina tylko i listowie.

A wielka śmierć, którą ma każdy w sobie,

to jest ów owoc, o który zabiega

wszelki byt ${ }^{22}$.

Tę myśl o jedyności własnej śmierci znajdujemy także u Leśmiana:

Każde zmarło inaczej śmiercią strasznie własną!...

Ciało matki i ojca i siostry i brata...

Dziś rysy waszych twarzy w pamięci mi gasną,

Umieracie raz jeszcze śmiercią spoza świata ${ }^{23}$.

Ale w tym wierszu pojawia się jeszcze myśl inna: śmierć nie jest zdarzeniem spełnionym raz na zawsze, śmierć powtarza się nieustannie w naszej świadomości, prócz śmierci „światowej” jest „śmierć spoza świata”. Czy dotyczy to tylko naszej świadomości?

Czy los człowieka, podejmującego nieskończone wyzwanie, nie oznacza także powtarzających się odejść, a więc swoistych śmierci, na drodze realizacji tego wyzwania? Być może tak należy odczytywać tajemnicze zdanie zawarte w wierszu Dziewczyna:

Lecz cieniom zbrakło nagle się, a cień się mrokom nie opiera!

I powymarły jeszcze raz, bo nigdy dość się nie umiera...

I nigdy dość, i nigdy tak, jak tego pragnie ów, co kona!... ${ }^{24}$

A więc i u Leśmiana spotykamy to przeświadczenie, że śmierć może nie być „własna”, nie ta, której „pragnie ów, co kona”.

\footnotetext{
${ }^{21}$ Tenże, Malte, dz. cyt., s. 25-26.

${ }^{22}$ Tenże, Poezje, dz. cyt., s. 33.

${ }^{23}$ B. Leśmian, Ubóstwo, [w:] tenże, Poezje, dz. cyt., s. 323.

${ }^{24}$ Tenże, Poezje, dz. cyt., s. 249.
} 


\section{5.}

Jest u Leśmiana jeszcze jeden, szczególnie ważny moment dotyczący istoty śmierci. Śmierć nie tylko „podmywa kontynent” czy „umniejsza świat". Śmierć, w tajemniczy sposób, obarcza winą tych, co zostają...

W każdym zgonie tkwi zbrodnia, co snem się powleka,

Chociaż zbrodniarza brak...

Wszyscy winni są śmierci każdego człowieka!

$\mathrm{O}$, tak! Na pewno - tak!

Winnych wskazać potrafię!... I nikt się nie broni!...

I ten - i ta - i ów!...

I ja sam! Ja - najbardziej, choć wiem, że i oni!

I ja - i oni znów...

Wina wszystkich naokół - milcząca, zbiorowa,

A my mówimy: »los«!

Niech od złego Bóg żywych i zmarłych zachowa!

Módlmy się o to $\mathrm{w}$ głos! ${ }^{25}$

Na czym polega wina, wina „milcząca, zbiorowa”? Czy na tym tylko, że zostaje się żywym? Że solidarnie nie przekroczyło się granicy, za którą znalazł się zmarły? Że odmówiło mu się towarzyszenia $w$ jego najcięższej próbie, czego wymaga zwykłe współuczestnictwo w człowieczeństwie? Jakby dalekim echem odbijały się słowa Anaksymandra:

$\mathrm{Z}$ czego zaś powstaje, to co istnieje, $\mathrm{w}$ to samo się obraca przez zniszczenie według koniecznego prawa, gdyż (...) jedno drugiemu płaci karą i pokutą za niesprawiedliwość według porządku czasu ${ }^{26}$.

To prawda: śmierć drugiego człowieka zawsze doświadczana jest jako akt szczególnej niesprawiedliwości. Ale inaczej, niż to się dzieje zazwyczaj, nasza pretensja do losu dotyczy nie nas, lecz drugiego. Dlaczego on - nie ja? Dlaczego w tej przygodności bytu, w którym z konieczności uczestniczymy, dokonał się taki, a nie inny wybór? Dlaczego zabrakło ocalenia?

Czy potrafimy dociec, jaka jest geneza tego poczucia winy, tak ostro i jak się zdaje - trafnie wyartykułowanego w wierszu Leśmiana? Nasuwa się przypuszczenie, że powodem jest - być może - nasza bezradność, niemożliwość żadnego sensownego odniesienia się do zmarłego. Gdy odchodzi ktoś, z kim związani byliśmy najgłębiej, kogo nic i nikt nie jest nam w stanie zastąpić, nasz żal jest nas zym żalem, rozpacz - nas zą rozpaczą. Nie "dotykają" one w najmniejszym stopniu zmarłego, bogacą - lub umniejszają

${ }^{25}$ Tenże, Do siostry, [w:] tenże, Poezje, dz. cyt., s. 318.

${ }^{26}$ Cyt. za: W. Heinrich, Zarys historii filozofii, t. 1, cz. 1, Filozofia grecka, Gebethner i Wolff, Warszawa-Kraków 1925, s. 19-20. 
- wyłącznie nas samych. Nie odnosimy także do zmarłego wyrazów współczucia: te kierowane są ku tym, którzy znaleźli się w sytuacji podobnej do naszej...

Więc obojętność? Więc to ona jest przyczyną poczucia winy? Wzdragamy się przed taką możliwością. A jednak wiemy, że i obojętność dochodzi do głosu i kładzie się cieniem na naszym stosunku do śmierci. Znamy ją z własnego doświadczenia, jej obezwładniającą obecność ukazywali i Breughel w Upadku Ikara i Miłosz w Campo di Fiori:

Tu na tym właśnie placu

Spalono Giordana Bruna,

Kat płomień stosu zażegnął

W kole ciekawej gawiedzi.

A ledwo płomień przygasnął,

Znów pełne były tawerny,

Kosze oliwek i cytryn

Nieśli przekupnie na głowach.

Wspomniałem Campo di Fiori

W Warszawie przy karuzeli,

W pogodny wieczór wiosenny,

Przy dźwiękach skocznej muzyki,

Salwy za murem getta

Głuszyła skoczna melodia

I wzlatywały pary

Wysoko w pogodne niebo ${ }^{27}$.

I jeszcze jeden wiersz ilustrujący motyw tym razem wręcz kosmicznej obojętności, krótki wiersz Tadeusza Różewicza:

Księżyc świeci

pusta ulica

księżyc świeci

człowiek ucieka

księżyc świeci

człowiek upadł

człowiek zgasł

księżyc świeci

księżyc świeci

pusta ulica

twarz umarłego

kałuża wody ${ }^{28}$

${ }^{27}$ Cz. Miłosz, Poezje, Czytelnik, Warszawa 1981, s. 75.

${ }^{28}$ Ze struny na strunę. Wiersze poetów Polski Odrodzonej, ułożył A. Lam, Wydawnictwo Literackie, Kraków 1980, s. 565. 


\section{6.}

Co będzie dalej? Co czeka człowieka po śmierci? Wiar i domysłów na ten temat jest najwięcej. Dobrze je znamy. Alternatywę najbardziej podstawową zarysował Sokrates:

Otóż jednym z dwóch jest śmierć. Bo albo tam niejako nic nie ma i człowiek po śmierci nawet wrażeń żadnych nie odbiera od niczego, albo jest to, jak mówią, przeobrażenie jakieś i przeprowadzka duszy na inne miejsce. Jeśli to brak wrażeń, jeśli to coś jak sen, kiedy ktoś śpiąc - nawet widziadeł sennych nie ogląda żadnych, toż przedziwnym zyskiem byłaby śmierć.

Jeżeli zaś śmierć, to niby przesiedlenie się duszy stąd na inne miejsce i jeżeli to prawda, co mówią, że tam są wszyscy umarli, to jakież może być większe dobro ponad n i ą, sędziowie!

Przecież jeżeli ktoś do Hadesu przybędzie, pożegnawszy się na zawsze z tymi rzekomymi sędziami, i znajdzie tam sędziów prawdziwych, jak to i mówią, że tam sądy odprawia Minos i Radamantys, i Ajakos, i Triptolemos, i innych półbogów, którzy za życia swego byli sprawiedliwi - to czyż to nie miła przeprowadzka? Albo tak spotkać Orfeusza i Muzajosa, i Hezjoda, i Homera, ileż by niejeden z was dał za to? Toż ja chcę częściej umierać, jeżeli to wszystko prawda ${ }^{29}$.

Problemu istnienia po śmierci nie da się rozstrzygnąć na gruncie filozofii: jest to sprawa wiary. A ta inspirowana tu nie tyle filozofią, ile poezją, by przypomnieć chociażby Boska komedię, dramaty Szekspira, Tren XIX albo sen Kochanowskiego, Fausta Goethego, Mickiewiczowskie Dziady czy Króla Ducha Słowackiego. Życie pozagrobowe uznane jest wszędzie tam za niepodważalny fakt, który intuicja poetycka pragnie zgłębić, zrozumieć rządzące nim prawa i objawić profanom. Zadziwiająca zgoda panuje co do tego, że w owym pośmiertnym stanie trymfuje ostatecznie jedynie sprawiedliwość.

Ale myślenie o stanie po śmierci obejmuje nie tylko zaświaty: stawia pytanie także o to, co pozostanie po nas tu taj. I znów jedno przeświadczenie wydaje się wspólne wszystkim odpowiedziom: otóż to, co pozostanie zależy przynajmniej częściowo od tego, jaką wartość miało nasze życie, a zwłaszcza od tego, co w nim udało się nam dokonać. Stąd ciąg wierszy powtarzających zapoczątkowany przez Horacego motyw exegi monumentum, stąd przeświadczenie o "sile fatalnej”, którą zostawia się potomnym, bo „zjadaczy chleba w aniołów przerobi".

Ale stąd także gorycz płynąca z doświadczenia życia oddanego na ofiarę, która - być może - nie zostanie ani przyjęta, ani doceniona:

${ }^{29}$ Platon, Obrona Sokratesa, 40c-41a, [w:] tenże, Eutyfron, Obrona Sokratesa, Kriton, przeł. W. Witwicki, Państwowe Wydawnictwo Naukowe, Warszawa 1958, s. 129-130. 
Nad nami - noc. Goreją gwiazdy,
dławiący, trupi nieba fiolet.
Zostanie po nas złom żelazny
I głuchy, drwiący śmiech pokoleñ ${ }^{30}$.

Ten motyw nieuchronnej, choć może niepozbawionej cienia nadziei klęski, która z konieczności ogarnie wszystko, co nastąpi po nas, ale w innym niż u Borowskiego, bo nie tylko pokoleniowym, ale wręcz ogólnoludzkim wymiarze, odzywa się w przejmującym Raporcie z oblężonego miasta Herberta:

\author{
(...) \\ cmentarze rosną maleje liczba obrońców \\ ale obrona trwa i będzie trwała do końca \\ i jeśli Miasto padnie a ocaleje jeden \\ on będzie niósł Miasto w sobie po drogach wygnania \\ on będzie Miasto \\ patrzymy w twarz głodu twarz ognia twarz śmierci \\ najgorszą ze wszystkich - twarz zdrady \\ i tylko sny nasze nie zostały upokorzone ${ }^{31}$
}

\title{
7.
}

Śmierć jest jak owoc, który dojrzewa w nas przez całe życie. Doświadczenie śmierci poucza jednak, że niekiedy bywa on przedwcześnie zerwany. Śmierć zdaje się przychodzić nie wtedy, gdy powinna. Najczęściej zdaje się przychodzić za wcześnie. Pocieszamy się: „Wybrańcy bogów umierają młodo", ale czy to nas uspokaja? Czy koi ból - i czy oddala to szczególne poczucie winy, o którym mówiliśmy poprzednio? Pozostaje przeświadczenie, że do śmierci trzeba dojrzeć. Czy mamy gwarancję, że tak się zawsze dzieje?

Rozważając sprawę indywidualności śmierci przytoczyliśmy początek wiersza Rilkego z jego Księgi godzin: „Każdemu daj śmierć jego własną, Panie". Oto dalszy ciąg tego wiersza:

A wielka śmierć, którą ma każdy w sobie,

to jest ów owoc, o który zabiega

wszelki byt. Rosną dziewczęta dla niego

i wybuchają niby drzewo z lutni,

chłopcy chcą zmężnieć w tęsknocie okrutnej;

kobiety stają się powiernicami

wyrostków, co swych trwóg nie dzielą z nikim.

Dla niego trwa to, co jest tu ujrzane,

\footnotetext{
30 T. Borowski, Pieśń, [w:] Ze struny na strunę..., dz. cyt., s. 534.

${ }^{31}$ Z. Herbert, Raport z oblężonego miasta i inne wiersze, Instytut Literacki, Paryż 1984, s. 82-83.
} 


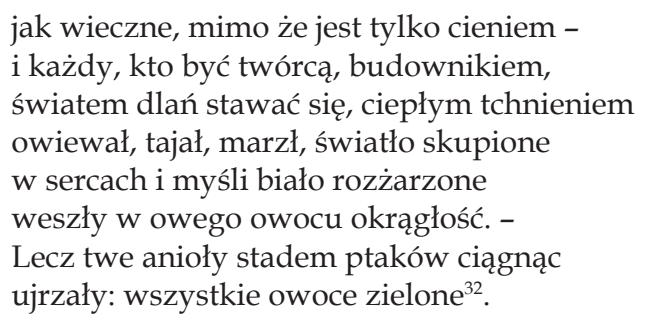

Niełatwo jest dojrzeć do śmierci. Nawet wtedy, gdy jej owoc zdawał się dojrzały, jego dojrzałość okazywała się złudą, istniała tylko quoad nos. Z perspektywy gwarantującej prawdę, perspektywy anioła, który w twórczości Rilkego zajmuje miejsce tak szczególne, była jeszcze przedwczesna. Lecz z czyjej winy to się stało? Czyż człowiek nie uczynił wszystkiego, by przyjął śmierć w sposób właściwy? Rilke, prosząc w modlitwie o własną, dojrzałą śmierć każdego, zdaje się być przerażony tym, że powszechnie dzieje się inaczej: śmierć nie staje się „własną", nie pozwala do siebie dojrzeć człowiekowi. Czy istnieje alternatywa dla tej sytuacji?

Ostatni człon Vade-mecum Norwida stanowi niezwykły wiersz zatytułowany Na zgon śp. Józefa Z., oficera Wielkiej-Armii, rannego pod Paryżem, jednego z naczelników powstania w Polsce. Ten wiersz zdaje się odpowiadać w pełni na nasze pytanie. Musimy przytoczyć go - na koniec naszych rozważań w całości.

\section{2}

O Herr gieb jedem seinen eigenen Tod.

Das Sterben, das aus jenem Leben geht, darin er Liebe hatte, Sinn und Not.

Denn wir sind nur die Schale und das Blatt.

Der grosse Tod, den jeder in sich hat,

das ist die Frucht, um die sich alles dreht.

Um ihretwillen heben Madchen an und kommen wie ein Baum aus einer Laute, und Knaben sehnen sich um sie zu Mann; und Frauen sind den Wachsenden Vertraute fur Angste, die sonst niemand nehmen kann. Um ihretwillen bleibt das Angeschaute wie Ewiges, auch wenn es lang verrann, und jeder, welcher bildete und baute, ward Welt um diese Frucht, und fror und taute und windete ihr zu und schien sie an. In sie ist eingegangen alle Warme der Herzen und der Hirne weisses Gluhn -: Doch deine Engel ziehn wie Vogelschwarme, und sie erfanden alle Fruchte grun.

R.M. Rilke, Poezje, dz. cyt., s. 32. 
Przedwieczny - którego nam odkrył Syn,

I o którym więc możemy mówić bezpiecznie,

Chociaż nigdy go nie widzieliśmy -

Przedwieczny - nie pragnie boleści tej,

Która osłupia serce ludzkie,

W wytrwały je zamieniając głaz.

Przenosi On ową raczej, która zwycięża

Siebie samą - - i z pociechami graniczy.

Ucho Jego pełne jest Miłosierdzia,

Ani rade słuchać jęków człowieczych;

Lecz skoro się gdzie nadłamie trawa polna,

Upuszcza On na nią kroplę rosy,

Która - z tak ogromnego Nieba -

Utrafia - na drobne miejsce swoje.

Dlatego to w Epoce, w której jest więcej

Rozłamań - niźli dokończeń...

Dlatego to w czasie tym, gdy więcej

Jest roztrzaskań - niźli zamknięć -

Dlatego to na teraz, gdy więcej jest daleko

śmierci niżeli - zgonów:

Twoja śmierć, Szanowny Mężu Józefie,

Doprawdy, że ma podobieństwo

Błogosławionego jakby uczynku!

Może byśmy już na śmierć zapomnieli

O chrześcijańskim skonu pogodnego tonie

I o całości żywota dojrzałego...

Może byśmy już zapomnieli doprawdy!...

Widząc - jak wszystko nagle rozbiega się

I jak zatrzaskuje drzwiami przeraźliwie;

Lecz, mało kto je zamknął z tym królewskim wczasem i pogodą,

Z jakimi kapłan zamyka Hostię w ołtarzu ${ }^{33}$.

Metafizyczny horyzont tego wiersza jest nieskończony ${ }^{34}$. Obejmuje całość, w którą „zaangażowany” jest i człowiek i Bóg, w szczególności - Jego Opatrzność: wszak to ona upuszcza kroplę rosy, która „utrafia na drobne miejsce swoje", by nie zginęła nałamana trawa polna, i by ból nie skamieniał na zawsze w sercu człowieka. Ból, cierpienie, a wreszcie i śmierć, nie są dziełem Boga: wszak - jak czytamy w wierszu Przeszłość:

${ }^{33}$ C. Norwid, Vade-mecum, oprac. J. Fert, Zakład Narodowy im. Ossolińskich, Wrocław 1990, s. $185-187$.

${ }^{34}$ Zob. znakomitą analizę tego wiersza, przeprowadzoną przez Stefana Sawickiego w jego książce Wartość - Sacrum - Norwid, Studia i szkice aksjologicznoliterackie, Redakcja Wydawnictw Katolickiego Uniwersytetu Lubelskiego, Lublin 1994, s. 76-80. Zob. także W. Stróżewski, Literatura i filozofia, „Ruch Literacki”, r. XXXVI, z. 6 (213) 1995, s. 703. 
Nie Bóg stworzył przeszłość i śmierć, i cierpienia,

Lecz ów, co prawa rwie ${ }^{35}$.

Tę prawdę potwierdza także Księga Mądrości:

Bo śmierci Bóg nie uczynił

i nie cieszy się ze zguby żyjących.

Stworzył bowiem wszystko po to, aby było ${ }^{36}$.

Dziełem Boga jest natomiast szczególna dialektyka boleści, dzięki której przezwycięża ona samą siebie „- i z pociechami graniczy”. Ta dialektyka obejmuje zresztą nie tylko fenomen bólu: w podobnym stosunku, w jakim pozostaje ból rozpaczy do bólu - pocieszenia, znajdują się rozłamania do dokończeń, roztrzaskania do zamknięć, a wreszcie śmierci do zgonów. Każdy z pozytywnych członów tych par oznacza przeciwne „rozbieganiu się" skupienie i jedność, a równocześnie zakłada dojrzałość całości życia. Jest więc dojrzałość możliwa do osiągnięcia, a anioły Rilkego, „stadem ptaków ciągnąc” nie muszą znajdować jedynie owoców zielonych...

Zgon, następujący po takim życiu, które doszło do swego „doskonałego dopełnienia", nie będzie tragicznym zatrzaśnięciem drzwi, za którymi pozostaje jedynie nieudana przeszłość i jej „nieznośne dnie”. Zgon to dokonanie, to zamknięcie - i to takie, jakim „kapłan zamyka Hostię w ołtarzu”. Pojawia się wielka symbolika drzwi, tak często przywoływana w rozważaniach o śmierci. Norwid nie mówi wprost ani o przejściu, ani o tym, co się po nim otworzy. Czyż jednak można było doskonalej wyrazić myśl o przejęciu ze sfery profanum do sfery sacrum, niż przywołując metaforę zamykanego tabernakulum? Pojawia się obraz hostii, tej samej, o której była mowa w Fortepianie Szopena:

...Hostię - przez blade widzę zboże...

Emanuel już mieszka

$\mathrm{Na}$ Taborze! $!^{37}$.

Życie dopełnione, zamknięte, życie uwieńczone nie śmiercią, lecz zgonem, zmienia się w życie przebóstwione. „Emanuel” znaczy przecież: „Bóg z nami". Dzieje się tak, jakby to życie przeniesione zostało do wnętrza tabernakulum, a to znaczy: do sfery boskości. Czyż nie tak właśnie należy rozumieć to, o czym już prawie na śmierć zapomnieliśmy: ów pogodny ton chrześcijańskiego skonu? Postawmy „kropkę nad i”: skonu, w którym mieści się zarówno dojrzałość (dopełnienie), jak przejęcie (przez zamykane, nie zatrzaskiwane drzwi), jak wreszcie znalezienie się w obliczu Emanuela.

\footnotetext{
${ }^{35}$ C. Norwid, Vade-mecum, dz. cyt., s. 20.

${ }^{36}$ Księga Mądrości 1,13-16, cyt. za: Bibliia Tysiąclecia, Poznań 1971.

37 C. Norwid, Vade-mecum, dz. cyt., s. 180.
} 
Norwidowska wizja śmierci jest wizją głęboko, autentycznie chrześcijańską. Dramatyczne pytania, które przywoływaliśmy poprzednio, znajdują w niej odpowiedź pełną nadziei. Boleść i rozpacz zmieniają się w ukojenie, brak $\mathrm{w}$ dopełnienie, przypadkowość chwili w jej dojrzałość, koniec $\mathrm{w}$ początek, rozbicie i rozbieganie $\mathrm{w}$ zjednoczenie $\mathrm{z}$ Bogiem. Trudno o piękniejszą, a zarazem bardziej optymistyczną koncepcję śmierci. Może więc jej przywołanie powinno zakończyć nasze rozważanie?

8 XII 1996

\section{On the experience of death}

Sum mary

The main goal of this article is to present death as portrayed in literature and especially in poetry (Rilke, Leśmian, Norwid). The author presents poetry and philosophy dealing with death experiences as well as other people's death. This article describes certain traumatic human emotions which accompany an experience of death. 
